\title{
Wildlife art and illustration: some experiments in Auroville, India
}

\author{
M. Eric Ramanujam ${ }^{1} \&$ S. Joss Brooks ${ }^{2}$ \\ ${ }^{1}$ Principal Investigator (Faunistics), ${ }^{2}$ Director, \\ Pitchandikulam Bioresource Centre/Pitchandikulam Forest Consultants, Auroville, Tamil Nadu 605101, India \\ Email: ${ }^{1}$ ericramanujam@yahoo.co.in (corresponding author), ${ }^{2}$ joss@auroville.org.in
}

\author{
Date of publication (online): 26 April 2011 \\ Date of publication (print): 26 April 2011 \\ ISSN 0974-7907 (online) | 0974-7893 (print) \\ Editor: Stephen D. Nash

\section{Manuscript details:} \\ Ms \# 02673 \\ Received 12 January 2011 \\ Final received 02 March 2011 \\ Finally accepted 17 March 2011
}

Citation: Ramanujam, M.E. \& S.J. Brooks (2011). Wildlife art and illustration: some experiments in Auroville, India. Journal of Threatened Taxa 3(4): 1702-1710.

Copyright: (C) M. Eric Ramanujam \& S. Joss Brooks 2011. Creative Commons Attribution 3.0 Unported License. JoTT allows unrestricted use of this article in any medium for non-profit purposes, reproduction and distribution by providing adequate credit to the authors and the source of publication.

Author Details: M. ERIC Ramanujam has been a wildlife illustrator for nearly two decades. Since 1997 he has been involved in full time conservation and has undertaken wildlife surveys in the Kaliveli region and Adyar wetland complex. His main sphere of interest is the natural history of the Indian Eagle Owl Bubo bengalensis. He heads the design and art studios in Pitchandikulam. S. Joss BRooks established Pitchandikulam, a forest community in Auroville, and was one of the pioneers of reestablishing the indigenous coastal vegetation of this region. He is the lead consultant to the prestigious Government of Tamil Nadu's Tholkappia Poonga eco-restoration project in Adyar, Chennai.

Author Contribution: MER prepared the manuscript with inputs from JB.

Acknowledgements: We are grateful to Chennai Rivers Restoration Trust (CRRT) for their permission to use images of artworks commissioned by them for the Tholkappia Poonga. We are also thankful to Nilgiri Biosphere Reserve Park for also allowing us to use images of commissioned works.

\begin{abstract}
The various media experimented with and some experiences have been discussed. The difference between traditional animal art (where religious and anecdotal insinuation, decoration and function are the onus) and wildlife art (where exactness to the natural form is the catchword) has been reiterated. The present schools of wildlife art (American and European) have been touched upon and so has the theory of our fascination for wildlife art.
\end{abstract}

Keywords: Conservation education, illustration, imagery, sensitisation, visual media, wildlife art.

India has a significant history of art, and animal motifs have always been part of its culture: from the time of the Mohenjendaro and Harappa civilizations (Grigson 1977; Pati \& Parpola 1987-1999), through the times of the ancient kingdoms (Walter 1958; Anselm \& Hermann 1965; Asher \& Spink 1989), to the medieval and Mughal period (Beach 1987, 1992; McKibben 1994), and even to this day. But animal motifs were and are still predominantly used for decorative and functional purposes, often with a religious or anecdotal insinuation. Such imagery, however impressive or awe-inspiring, cannot be termed 'wildlife art' in the true sense of the term. Wildlife art, as understood in the modern (and scientific and naturalistic) sense, and propagated by the likes of Ralph Thompson, Sir Peter Scott, Robert Bateman, Arthur Singer, David Shepherd and other stalwarts of the genre, is where the artist has sought and captured an exactness of proportion, form and detail. The striking divide between animal art for decorative and other purposes, and wildlife art is obvious within the Mughal School (1526-1857) itself. While Jalaludin Muhammed Akbar (1542-1605) was interested in historical and mythological events, Jehangir introduced portrait studies of fauna (Khanam 2009). In this sense, Nurud-din Salim Jehangir (1569-1627) can be considered to be the patron of the first wildlife artists in India, and as he himself was proficient with brush and pen, can be credited with being among the first wildlife artists in the country. As is a feature of the Mughal School, these portraits lacked depth, but the exactitude of proportion, line and colour showed a keen sense of observation and naturalistic rendering, a feature of wildlife art.

Painting was a passion at the Mughal court and the first Europeans to seek trading favours in India brought paintings from their countries as presents or as items of trade.

From the 1780s, India became a major attraction for a stream of painters from England. With them arrived the art of illusionist oil painting and naturalistic watercolours and, in association, the techniques of aquatint 
engraving and lithography (Guha-Thakurta 1992, 2003). These paintings introduced Indian painters to perspective, foreshortening, depth, and light and shade. Thus painters gradually changed their concepts and compositions in response to foreign influence and imperial taste (Beach 1987). By the time of the British rule, realism was the feature of art in the 'educated circles' of those times. During a period when photography was non-existent or rudimentary or nonapplicable to biological studies, illustration was the only medium for representation. Great heights were scaled by wildlife artists during that period (eg., Gould 1832) and many of their works and reproductions are sought after collector's items today. Scientific illustration too employed many artists and draftsmen and their work can be seen in many books of that time (eg. Day 1889) and the trend continued well into the next century (eg. Pocock 1939, 1941). And then came the period of illustrated field guides when many artists of Indian origin like J.P. Irani, Carl D'Silva, Maya Ramaswami and Arnab Roy (Ali 2002; Grimmet et al. 1998; Shawl et al. 2009), to name a few, came to prominence.

Today,inspiteofformidableadvancesinphotography and cinematography, art and illustration still hold their ground because its appeal is widespread and almost universal, with vast potential for use in conservation education (Nash 2009). The art and science of wildlife imagery has been experimented with by many, if not all, reputed conservation organizations and the outputs have been found to be quite encouraging. The reasons, still a subject of intense debate, may be imbued in us, as the first symbols of humankind were animals, the first paint was probably animal blood, and for thousands of years the human experience of the world was charted using animal signs (Berger 1980). Wilson (1984) pioneered 'biophilia' - a need we feel for the presence of other creatures around us, essential for the continued health of our own species. Add to this the evolutionary biologist's point of view that there is an innate compulsion encoded in our genes - akin to our tendency to engage in conflict and altruism, and that 'feelings' of 'dislike', 'fear', 'compassion' and 'love' are part of our genetic makeup (Dawkins 1976; Goodall 1999) - and we have a case why imagery is so crucial to progressive thought. Whatever the reason, today we continue to represent and share our experiences of wildlife through imagery, and with the availability of a variety of different media, everyone can express their interpretation in a personal way. Wildlife art seeks not only to generate an appreciation of and enthusiasm for the natural world, but also advance the interest, education and concern of the public in the conservation of wildlife.

The experiments at Pitchandikulam in Auroville International Township carry on the tradition where naturalism, exactitude and dissemination of information are the catchwords. Pitchandikulam was established in 1973 and since then it has been experimenting with imagery to sensitize people to the need to conserve native biodiversity, especially the coastal forests, popularly referred to as the Tropical Dry Evergreen Forest (TDEF for short) and its denizens. It has experimented with various media. Some of the materials and methods employed so far are discussed below.

Painting on Kadapa stone slabs: Kadapa stone, also known as Cuddapah stone (from the original Telugu, Gadapa) and Kadapa Black or Madras Black (the latter two trade names), is basically a black limestone intruding into other rocks (quadrites, dolmites and shale). While the pure black rock slabs are polished and used in interiors, the impure slabs which contain other rock types show a variety of colours and textures in the unpolished form. It is these unpolished stone slabs that are used in painting. The challenge of painting on stone is to use the natural colours and textures to advantage (Images 1-3). This demands clear cut composition of the theme to be portrayed and minimal painting of backgrounds. In fact, the crux lies in the background painting (or degree of the lack of it) as backgrounds should enhance the natural colours and textures, not suppress them.

Painting on boulders: The onus here is to use the shape of the stone to form the natural contours of the animal (Image 4).

Stone sculpture: Unlike the puristic stone carvings, the art forms produced so far have combined carving with painting to bring out form, texture and natural colours of the creatures depicted. Carvings on stones (Images 5-6, 8-10) have been produced as art forms in their own right or combined with other media to suit a purpose (for example, granite pillars combined with painted wooden planks were found most suitable for directional signage (Image 7)).

Ferro cement sculpture: Scaled up versions of 


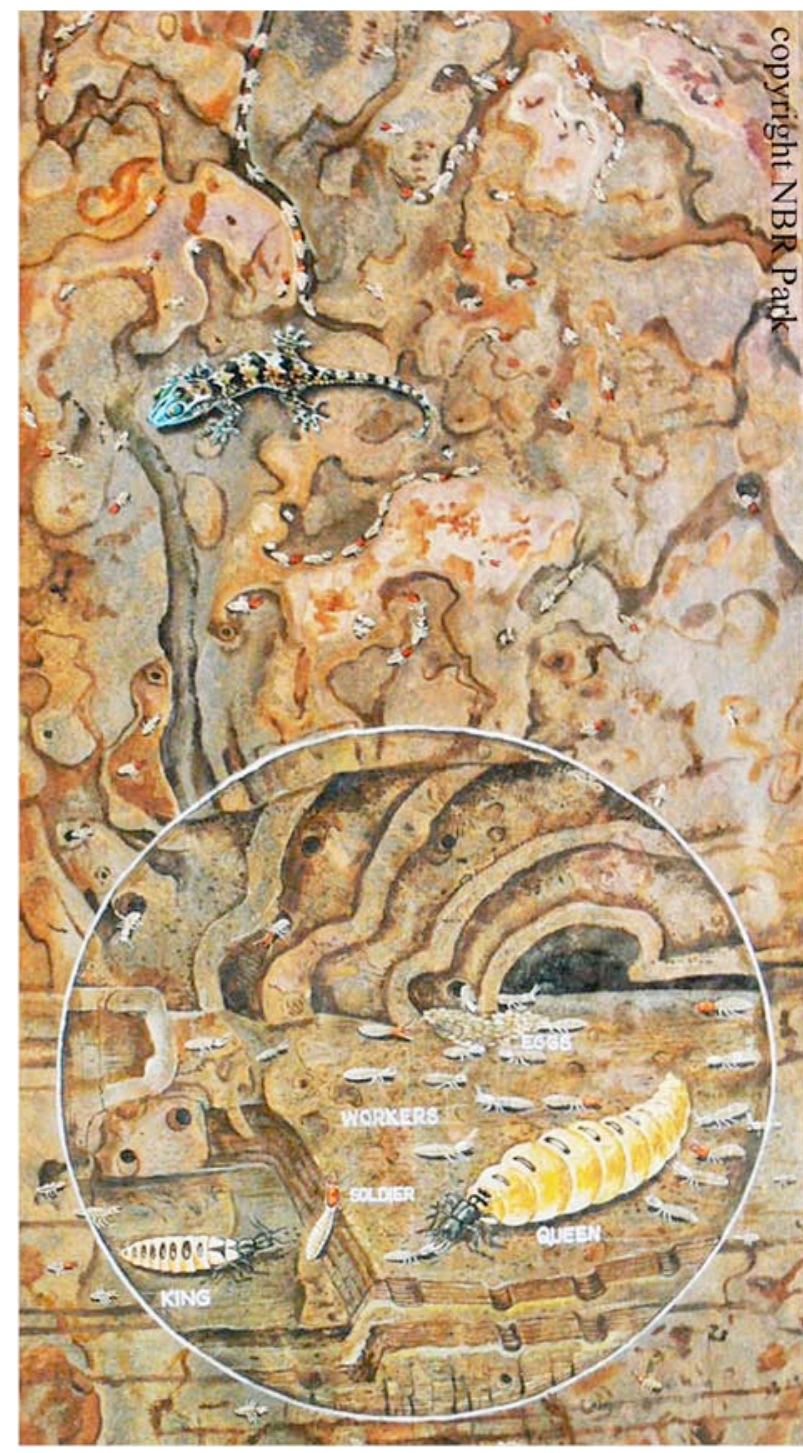

Image 1. The challenge of painting on stone is not to tamper too much with its intrinsic features. An eroded Kadappa stone slab was chosen to represent the interior of a termite mound with the highlight being the queen's chamber (encircled). An added touch was the utilization of a Termite Hill Gecko Hemidactylus triedrus that has just shed its skin (if a normal specimen had been represented it would not have stood out from the background). Nilgiri Biosphere Park, Anaikatti.

animals were found to be eye-catching and popular (Images 11-13). The onus here is on strength and durability since most, if not all, sculptures were designed to occupy public spaces where they are accessible to the public. Life size models have also been produced. It was found more satisfying to represent fish, amphibians, reptiles and birds rather than mammals because fur does not translate easily to this medium.

Mosaic: Wildlife art is a forum of imagery that will

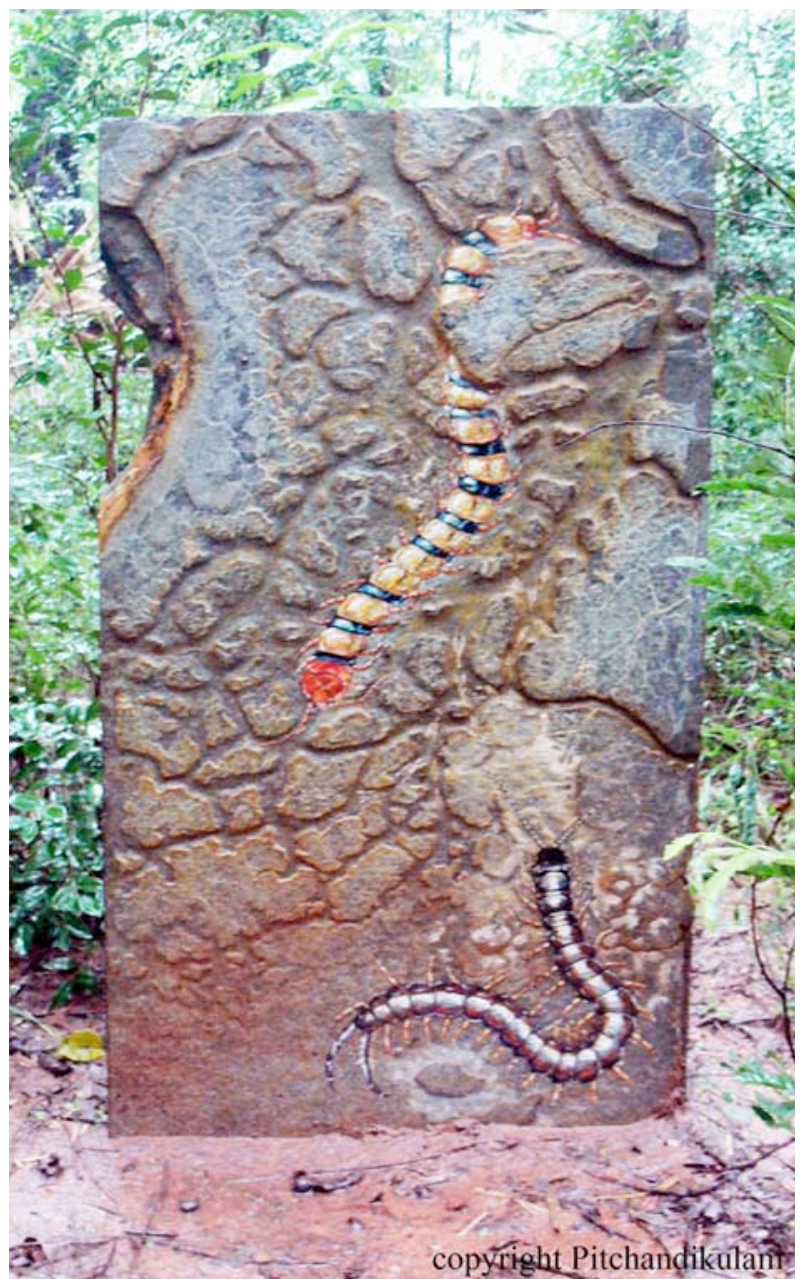

Image 2. Irregularity of form of the base material is always a challenge - in this case a 'broken' eroded stone slab like the last one, but with an even more irregular surface. The artist took the opportunity to represent a Centipede Scolopendra hardwickii seemingly moving under an overhang in its distinctive way. Pitchandikullam Forest, Auroville.

hold one's interest and validate the passion for wildlife but occasionally it has the potential to push us out of our comfort zone. One such medium that borders on the abstract is mosaic. But unlike the majority of mosaics depicting animals the experiments here have a strong element of realism particularly where form, proportion and colour are concerned. The advantage of mosaic over painting is that it is permanent, though detail cannot be incorporated. Nevertheless, such semiabstract visual solutions can be useful in conveying graphic information (Images 14-16).

Poster Art: It is said that a picture speaks a thousand words, and though photography can capture a moment, art can share an entire experience and is a 


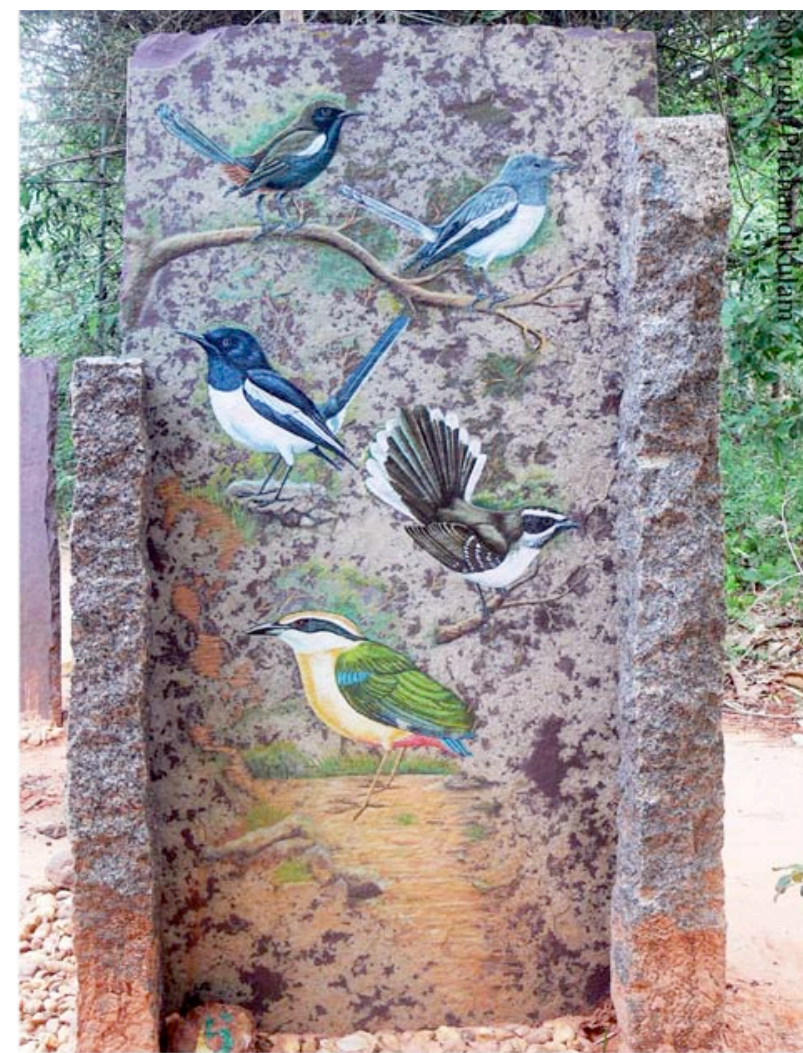

Image 3. Mild tampering is sometimes required to make a point - in this case to represent different niches occupied by birds in a coastal forest along the southern Coromandel Coast. That is why the ground has been painted in, but very minimally. The natural 'cloudy' tone of the stone has been maintained to represent foliage. A minimal amount of green was used to make the subject stand out from the background. The use of rough cut granite pillars to frame the slab is another added touch. Species represented are Indian Robin Saxicoloides fulicata, Oriental Magpie Robin Copsychus saularis, White-browed Fantail Rhipidura aureola and Indian Pitta Pitta brachyura. Pitchandikulam Forest, Auroville.

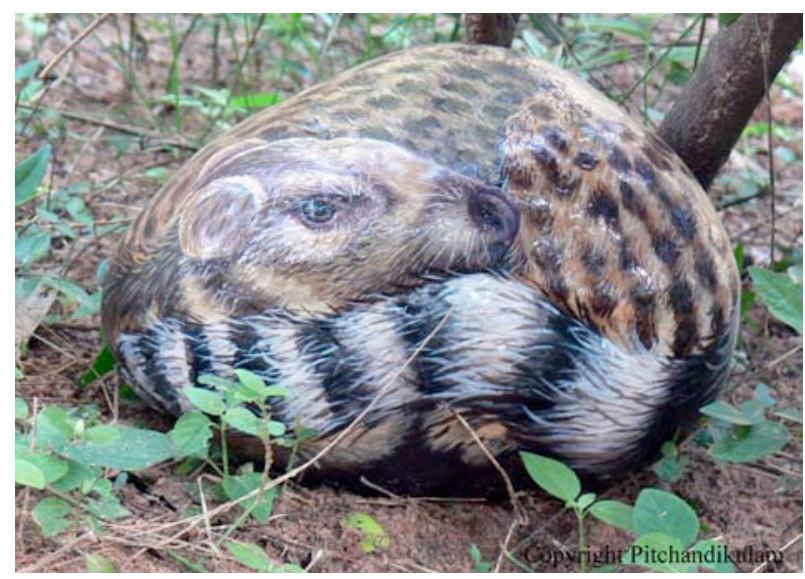

Image 4. A boulder painted to represent a life-sized curled up Small Indian Civet Viverricula indica. A photograph can do only 'so much' and the naturalness of this form has to be seen to be believed. Even seasoned wildlifers have been startled when confronted with this piece in its natural surroundings. Pitchandikulam Forest, Auroville.

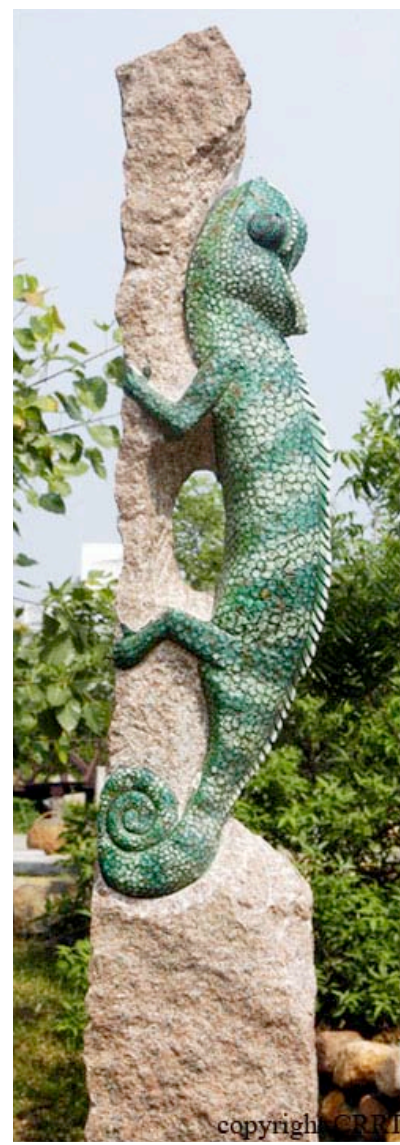

Image 5. Vertically implanted rough hewn granite pillars carved and painted over was found charming. This is a scaled up version of the Indian Chameleon Chamaeleon zeylanicus nearly $1 \mathrm{~m}$ long. Tholkappia Poonga, Chennai.

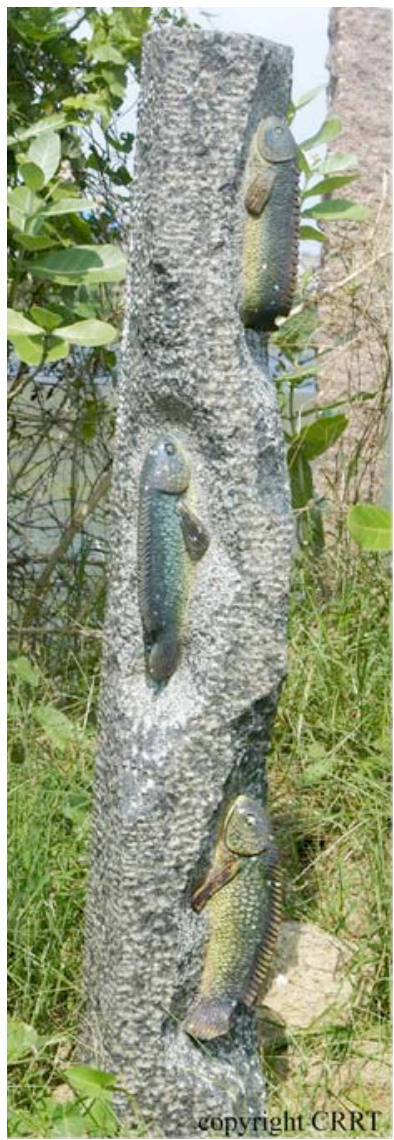

Image 6. Even life sized representations can be interesting - in this case three Climbing Perch Anabas testudineus. These fish were observed actually climbing up granite pillars of huts and walls at this particular site (the holotype was found in a palmyra tree). Tholkappia Poonga, Chennai.

unique way of seeing and sharing the world $(<$ www. bbcwildlifemagazine.com/artist2009.esp $>$ ). Poster art, perforce being visually striking and designed to attract attention, was found to be one of the best tools for conservation education (Image 17). The genre of poster art produced was a combination of research poster and classroom poster as the need was to produce a simple 'one image' format that could sensitise people to the biotic wealth of the region as well as being scientifically accurate. Poster art from the time of Toulouse-Lautrec and Cheret had depended on colour, but black and white images were also used - for example, the poster publicizing the Exposition Universelle of 1905 at Liege. Both colour and black and white (ink) have been experimented with and the 


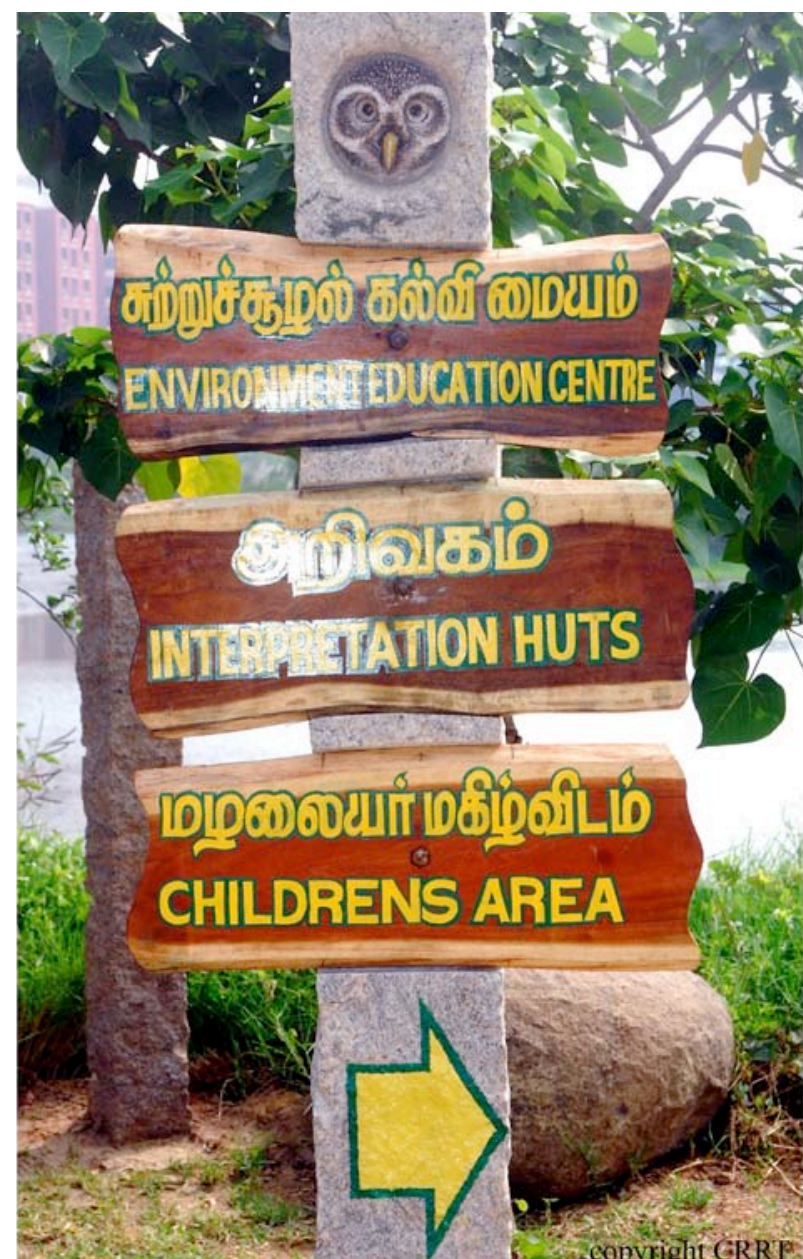

Image 7. A carved and painted Spotted Owlet Athene brama peering out of a cavity tops another rough hewn granite pillar to which planks with directional signage have been affixed. Tholkappia Poonga, Chennai.

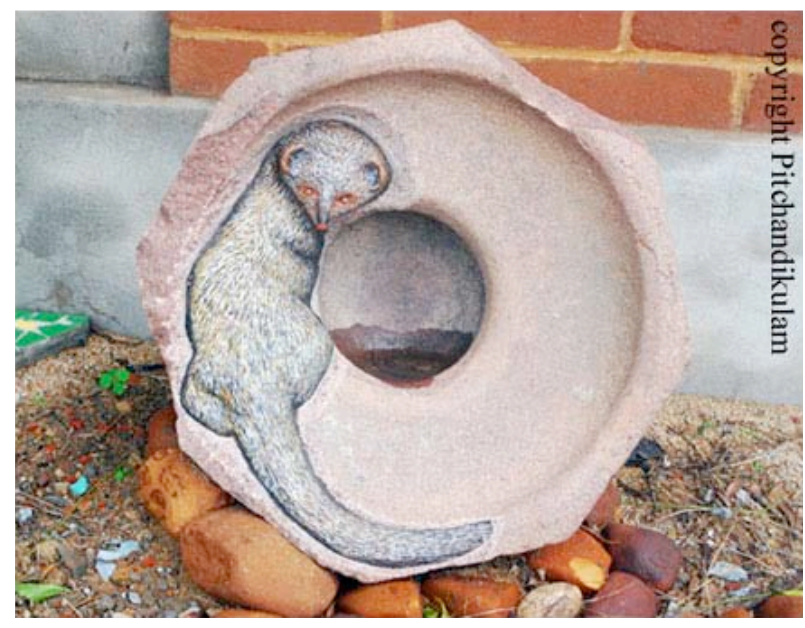

Image 8. Sometimes even waste can be utilized - in this case a disused mortar has been carved in relief and painted over to represent the Grey Mongoose Herpestes edwardsi. The challenge was to satisfactorily represent the 'ticked' fur in minimal detail which is the feature of the species and so hard to paint. Pitchandikulam Forest, Auroville.

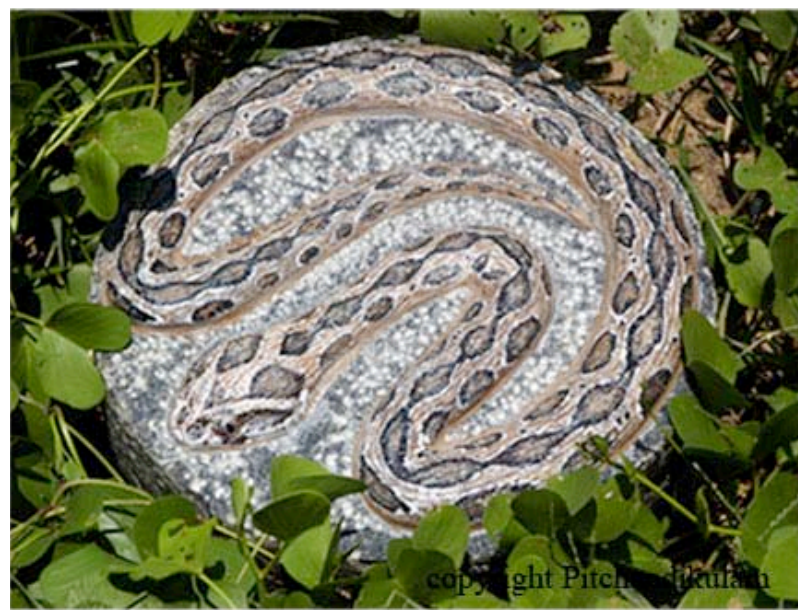

Image 9. A disused grinding stone carved and painted to represent a Russell's Viper Daboia russelii. Placed among herbage it has caused some consternation among the uninitiated. Pitchandikulam Forest, Auroville.

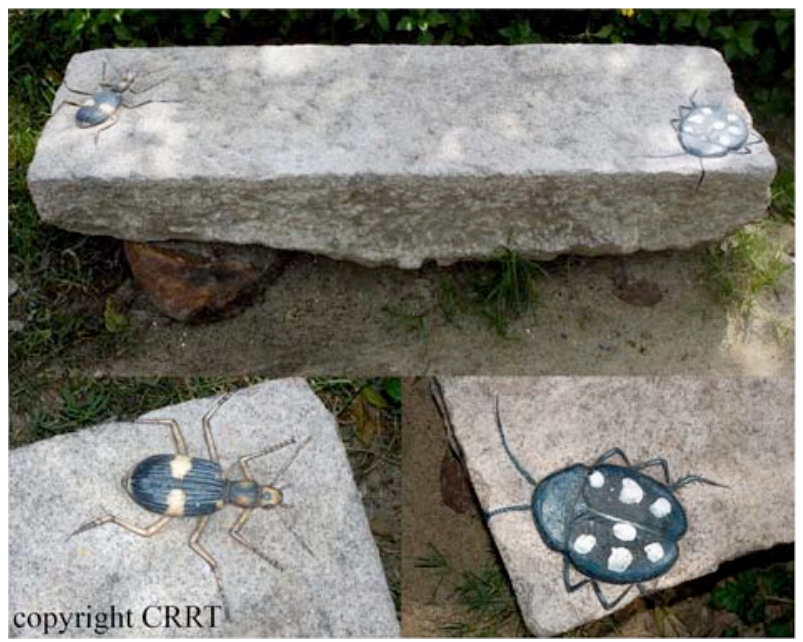

Image 10. An example of carved granite blocks used as benches. Species represented: Bombardier Beetle Macrocheilus niger and Domino Roach Therea petiveriana. Tholkappia Poonga, Chennai.

results found quite satisfactory.

The work at Pitchandikulam has leaned a lot toward the American School of wildlife art. Both the European School (which relies more on field work and spontaneity) and the American School (which is more studio oriented and technical) have their advantages, although the American has the upper hand today because the fashion is 'ultra realism' due to the 'Wyeth syndrome'.

Field culture or studio culture? The conundrum is very poignantly reflected by the art critic Brown (2000) who described the great David Shepherd's 


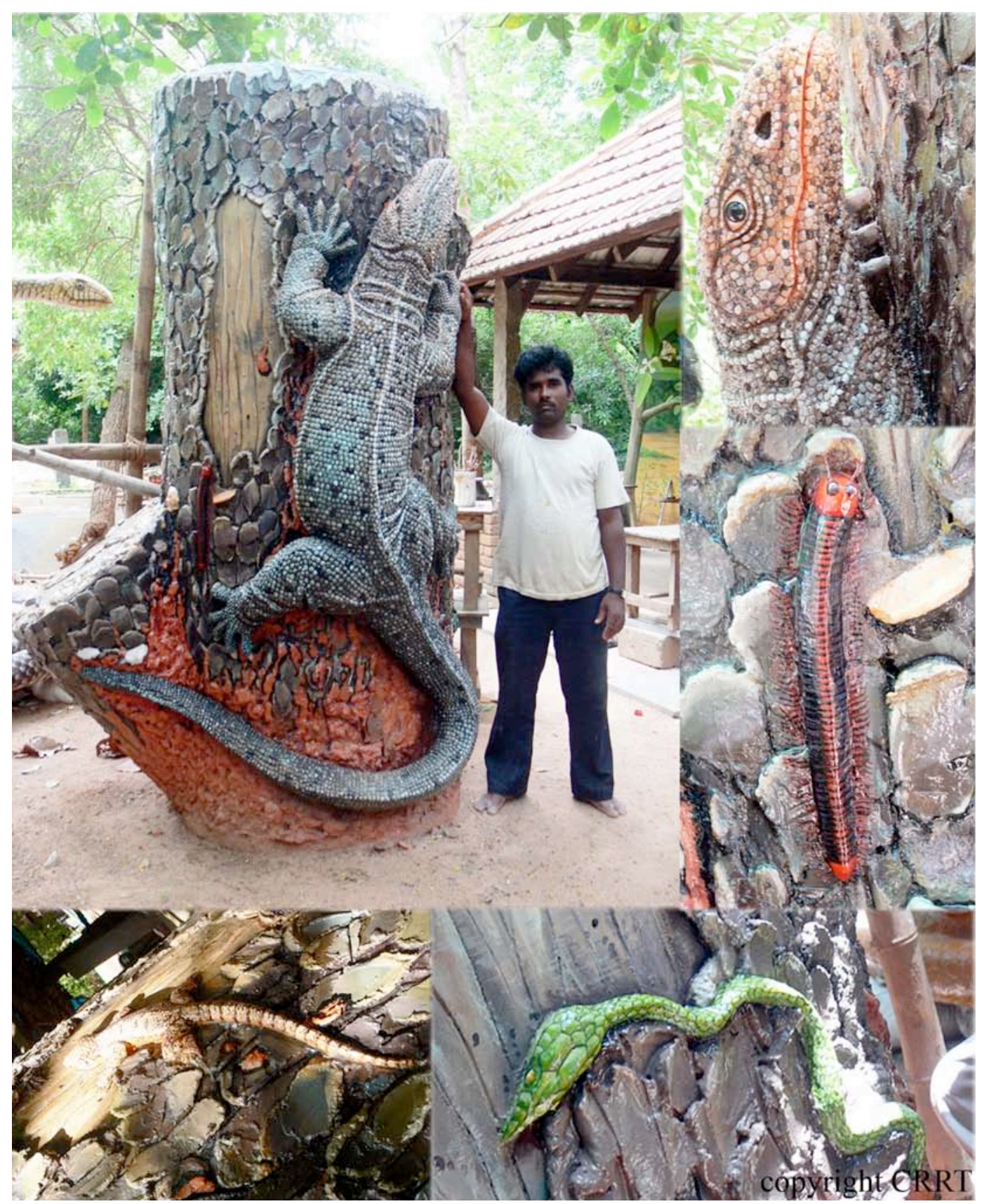

Image 11. Scaled up versions of animals were found to be dynamic and eye-catching. In this case an Indian Monitor Lizard Varanus bengalensis. In addition to the lizard, the tree trunk to which it clings also supports other faunal elements like the Green Vine Snake Ahaetulla nasutus, Brook's Gecko Hemidactylus brooki and Red-lined Millepede Xenobolus acaticonus in addition to others. Tholkappia Poonga, Chennai.

work (European School) in the following way: "It is Shepherd's shortcomings that make him interesting ....... the point of which his technical and artistic abilities fail him" on one hand, and "There is something exciting about the artist's extreme overconfidence and unabashed sentiment, and, in spite of working within a tradition of such art, something frightfully authentic". Pitchandikulam would like to take issues to the next level, viz., to achieve the fine balance between field and studio cultures, but that is easier said than done. This does not mean that we are about to try to replicate Shepherd's methodologies - to quote Durrell (1990) "Before I met him for the first time I was told that I was bound to get on with him as we were as mad as each other. When we met, I grant you there were certain similarities but I still maintain that David has the edge 


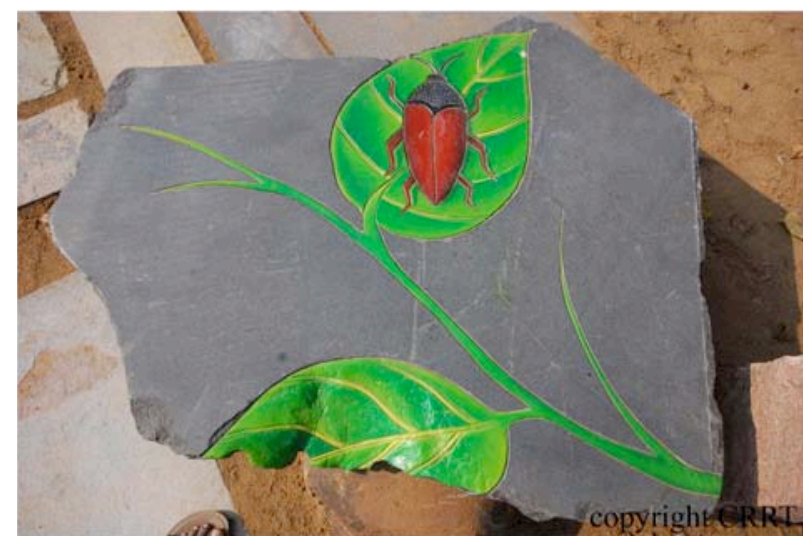

Image 12. Relief may represent form, but simple etching of outlines and painting the interior can also make a subject stand out from its surroundings. The challenge here is to use the shape of the base material to advantage and to create an 'effect'. Here the uneven edge of discarded waste from a TAMIN factory has been used to advantage. Species represented: Jewel Beetle Sternocera sp. Tholkappia Poonga, Chennai.

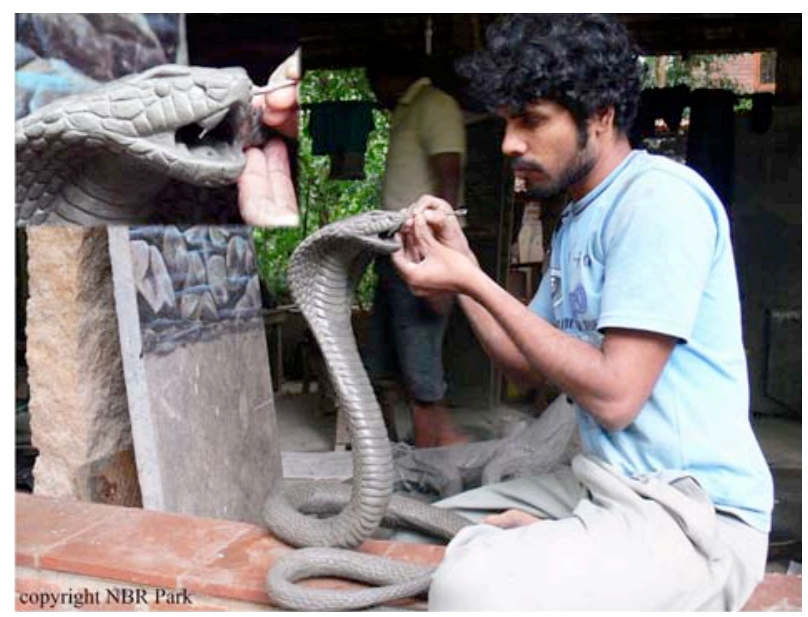

Image 13. An artist working on a yet to be finished life sized ferro cement model of an Indian Cobra Naja naja. Detail is crucial to such efforts - every scale has to be faithfully represented, including the small cunate scale among the infralabials. Commissioned by Nilgiri Biosphere Reserve Park, Anaikatti.

over me, for I would not be so idiotic to go palette in hand, trailing a BBC crew, in an effort to paint an original portrait of an elephant in the wild. I forget how many times they were charged in this ridiculous and dangerous process but I know Chris Parsons who produced it, came back from Africa with grey streaks in his hair and a haunted look in his eyes".

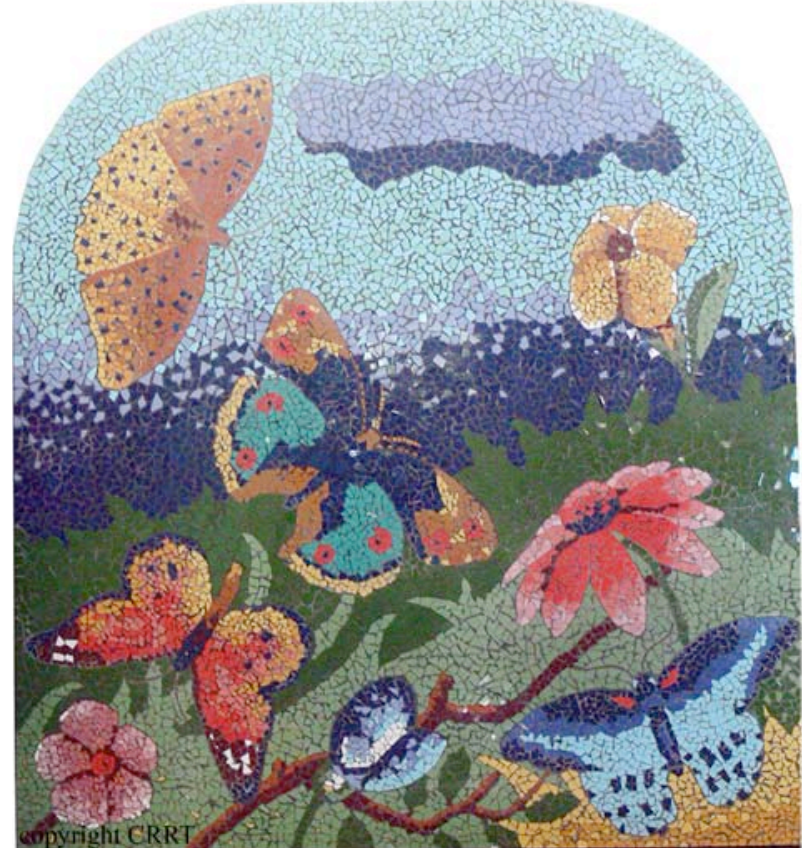

Image 14. Mosaic panel - one panel from a set of three depicting butterflies of the southern Coromandel Coast. Species represented: Common Leopard Phalanta phalantha, Blue Pansy Junonia orithya, Plain Tiger Danaus chrysippus and Blue Mormon Papilio polymnester. Tholkappia Poonga, Chennai.

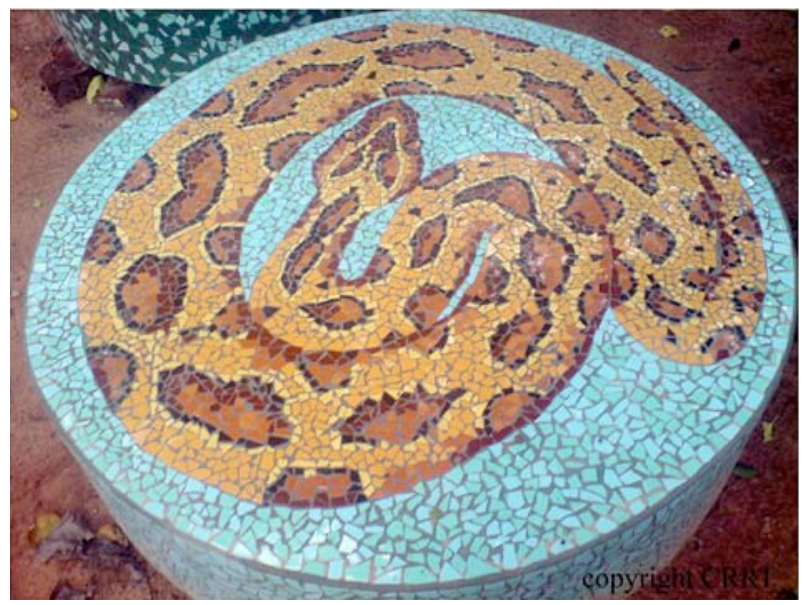

Image 15. Richness of colour is one feature of mosaic work that cannot be equaled by any other media. The cement ring which is used for seating is adorned by a Russell's Viper Daboia russelli. Tholkappia Poonga, Chennai.

\section{REFERENCES}

Ali, S. (2002). The Book of Indian Birds. $20^{\text {th }}$ Edition. Bombay Natural History Society and Oxford University Press, 326pp.

Anselm, J. \& G. Hermann (1965). Mallapuram and the World 


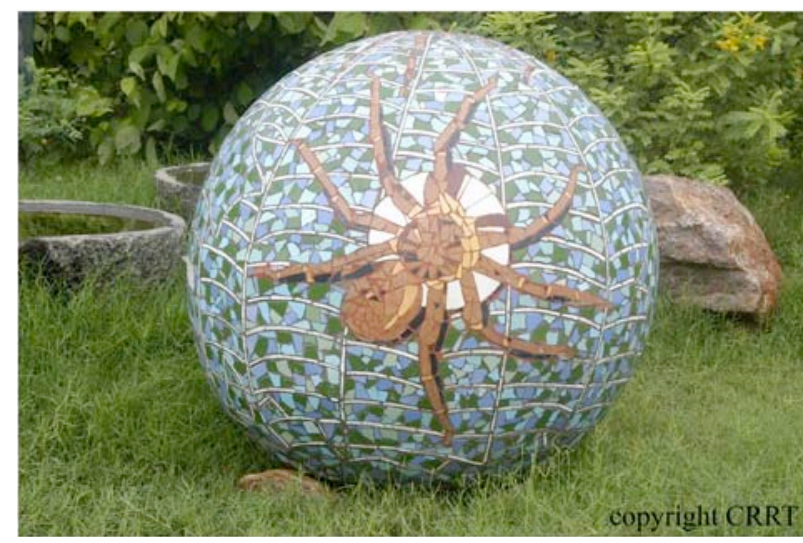

Image 16. A mosaic of a Giant Crab Spider Heteropoda venatoria holding its egg case adorns a ball approximately $1 \mathrm{~m}$ in diameter. Tholkappia Poonga, Chennai.

of South Indian Art. Scherpe Verlag, Krefelt, xxxpp.

Asher, F. \& W. Spink (1989). Maurya Figural Sculpture Reconsidered. Ars Orientalis 19: 1-25.

Beach, M.C. (1987). Early Mughal Painting. Harvard University Press, $164 \mathrm{pp}$.

Beach, M.C. (1992). Mughal and Rajput Painting. Cambridge University Press, Cambridge.

Berger, J. (1980). "Why Look At Animals". "About Looking”. Readers and Writers Publishing Cooperative, London.
Brown, N. (2000). David Shepherd. Frieze Magazine 51: 26.

Dawkins, R. (1976). The Selfish Gene. Oxford University Press, NY, 384 pp.

Day, F. (1889). The Fauna of British India including Ceylon and Burma. Fishes. 2 vols. Taylor \& Francis, London. 544 \& 509 pp.

Durrell, G. (1990). The Ark's Anniversary. Collins, London, $179 \mathrm{pp}$.

Goodall, J. (1999). Reason for Hope - a spiritual journey. Soko Publications Ltd. \& Phillip Berman, 282pp.

Gould, J. (1832). A Century of Birds from the Himalayan Mountains. Letterpress by N.A. Vigors.

Grigson, C. (1977). Some Thoughts on Unicorns and Other Cattle Depicted at Mohenjo-daro and Harappa. South Asian Archaeology. Eds: Allehin, B. and F.R. Allchin. Cambridge University Press, pp.166-169.

Grimmett, R., C. Inskipp \& T. Inskipp (1998). Birds of the Indian Subcontinent. Oxford University Press, Delhi, 888pp.

Guha-Thakurta, T. (1992). The Making of a New "Indian" Art: Art, Aesthetics, and Nationalism in Bengal, c. 1850 1920. Cambridge University Press.

Guha-Thakurta, T. (2003). The Period of Colonisation and Nationalism, c., 1757-1947. Asher, F.M. (ed.). Art in India: Prehistory to the Present, pp. 109-128.

Khanam, Z. (2009). Birds and Animals in Mughal Miniature Painting. Eastern Book Corporation, xvi+164pp+71pl.

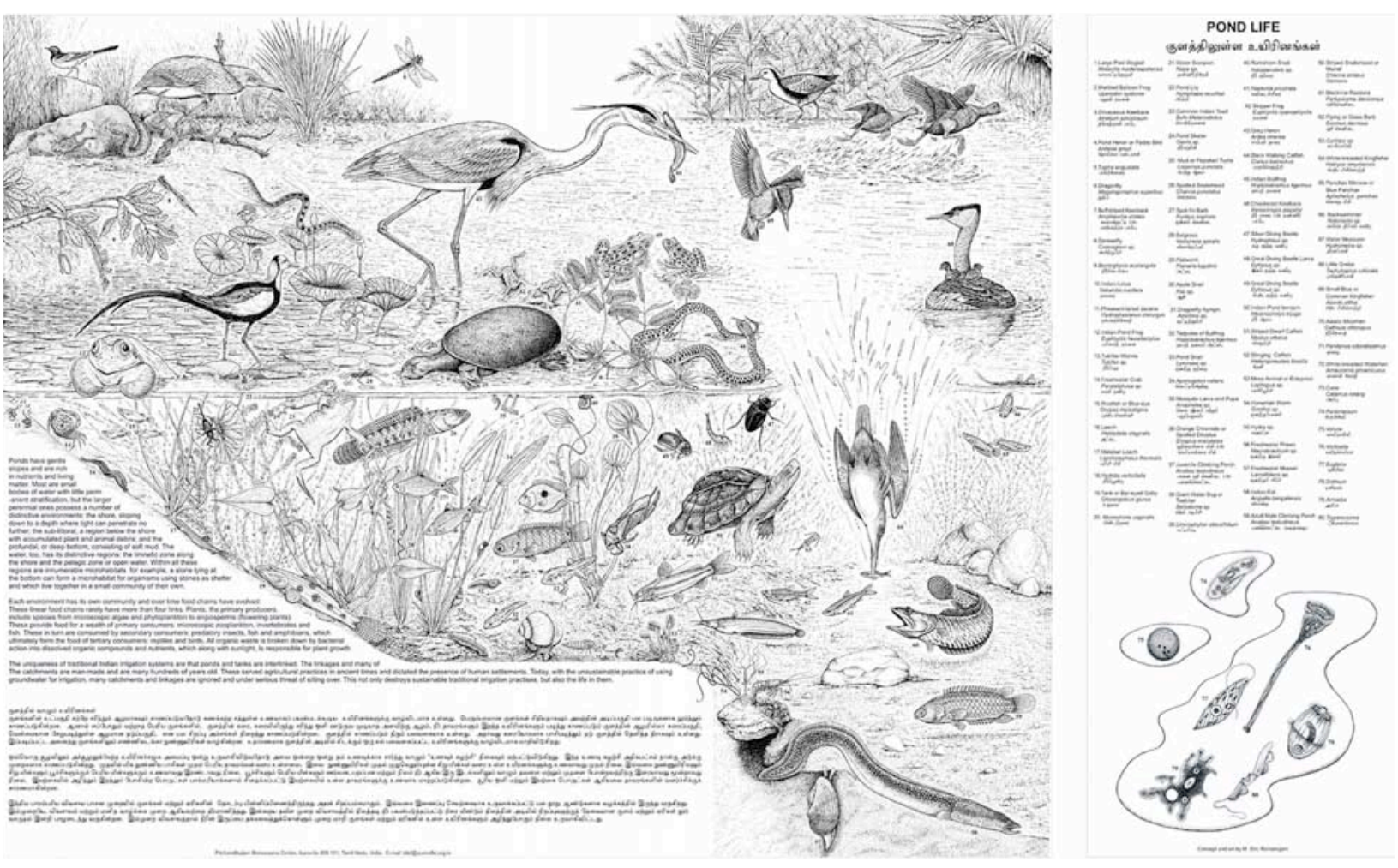

Image 17. Pen and ink representation of life in a typical pond along the southern Coromandel Coast of India. The drawing is interspersed with informative text and $\mathbf{8 0}$ species have been represented (from vertebrates to microscopic life). A feature of this poster is the 'undercurrent' graphic representation of the web of life (with predation playing a major role). 
McKibben, W.J. (1994). The Monumental Pillars of Firuz Shah Tughluq. Ars Orientalis 24: 105-118.

Nash, S.D. (2009). Some thoughts and reflections on the use of illustration in Biodiversity Education Campaigns. Journal of Threatened Taxa 1: 119-125.

Pati, J.J. \& A. Parpola (1987-1999). Corpus of Indian Seals and Inscriptions. 2 vols. Suomalaineu Tiedeakatemia, Helsinki.

Pocock, R.I. (1939). The Fauna of British India including Ceylon and Burma. Mammalia-Vol I. Primates and Carnivora (in part), Families Felidae and Viverridae. Taylor \& Francis, London, 463pp.
Pocock, R.I. (1941). The Fauna of British India including Ceylon and Burma. Mammalia-Vol II. Carnivora (continued from Vol I), Suborders Aeluroidea (part) and Arctoidea. Taylor \& Francis, London, 503pp.

Shawl, T., J. Takpa, P. Tashi \& Y. Panchaksharam (2009). Field Guide to the Mammals of Ladakh. WWF-India and Dept. of Wildlife Protection, Govt. of Jammu and Kashmir, India.

Walter, S. (1958). On the Development of Early Buddhist Art in India. Art Bulletin 40: 95-104.

Wilson, E.O. (1984). "Biophilia". Harvard University Press, Massachusetts. 